\title{
Erratum to: Persistence and Profiles of Tetracycline Resistance Genes in Swine Farms and Impact of Operational Practices on Their Occurrence in Farms' Vicinities
}

\author{
Andrei L. Barkovskii • Candace Bridges
}

Published online: 4 May 2012

(C) Springer Science+Business Media B.V. 2012

\section{Erratum to: Water Air Soil Pollut \\ DOI 10.1007/s11270-011-0838-1}

In the original publication of this article, Online Resource 3, the line "Farm 2 tetX May-07 sampling" should be read as Farm 2 tetW May-07 sampling, and vice versa". 